\title{
Burden of herpes zoster requiring hospitalization in Spain during a seven-year period (1998-2004)
}

\author{
Angel Gil*1, Ruth Gil ${ }^{1}$, Alejendro Alvaro' ${ }^{1}$, María San Martín ${ }^{2}$ and \\ Antonio González ${ }^{2}$
}

\author{
Address: ${ }^{1}$ Department of Health Sciences, Rey Juan Carlos University, Avda de Atenas s/n, 28922 Alcorcón, Madrid, Spain and ${ }^{2}$ Medical \\ Department, Sanofi Pasteur MSD, P $^{\circ}$ de la Castellana 141, 28046 Madrid, Spain \\ Email: Angel Gil* - angel.gil@urjc.es; Ruth Gil - ruth.gil@urjc.es; Alejendro Alvaro - alejandro.alvaro@urjc.es; María San \\ Martín - msanmartinrodriguez@spmsd.com; Antonio González - agonzalezlopez@spmsd.com \\ * Corresponding author
}

\section{Published: 7 May 2009}

BMC Infectious Diseases 2009, 9:55 doi:10.1/86/1471-2334-9-55

This article is available from: http://www.biomedcentral.com/147I-2334/9/55

(c) 2009 Gil et al; licensee BioMed Central Ltd.

This is an Open Access article distributed under the terms of the Creative Commons Attribution License (http://creativecommons.org/licenses/by/2.0), which permits unrestricted use, distribution, and reproduction in any medium, provided the original work is properly cited.
Received: 24 September 2008

Accepted: 7 May 2009

\begin{abstract}
Background: A thorough epidemiological surveillance and a good understanding of the burden of diseases associated to VZV are crucial to asses any potential impact of a prevention strategy. A population-based retrospective epidemiological study to estimate the burden of herpes zoster requiring hospitalization in Spain was conducted.
\end{abstract}

Methods: This study was conducted by using data from the national surveillance system for hospital data, Conjunto Mínimo Básico de Datos (CMBD). Records of all patients admitted to hospital with a diagnosis of herpes zoster (ICD-9-MC codes 053.0-053.9) during a 7-year period (1998-2004) were selected.

Results: A total of 23,584 hospitalizations with a primary or secondary diagnosis of herpes zoster in patients $\geq 30$ years of age were identified during the study period. Annually there were 13.4 hospitalizations for herpes zoster per 100,000 population in patients $\geq 30$ years of age. The rate increases with age reaching a maximum in persons $\geq 80$ years of age $(54.3$ admissions per 100,000 population $>80$ years of age). The mean cost of a hospitalization for herpes zoster in adult patients was $3,720 €$. The estimated annual cost of hospitalizations for herpes zoster in patients $\geq 30$ years of age in Spain was 12,731,954€.

Conclusion: Herpes zoster imposes an important burden of hospitalizations and result in large cost expenses to the Spanish National Health System, especially in population older than 50 years of age

\section{Background}

It is estimated that the $15 \%$ of the population will suffer from herpes zoster (HZ) at least once in their lifetime [1]. Complications of herpes zoster occurs in $13-26 \%$ of the cases $[2,3]$. Post-herpetic neuralgia (PHN) is the most common and debilitating [4,5], affecting 15 to $40 \%$ of cases. $[3,6]$. The incidence and severity of herpes zoster and postherpetic neuralgia increase with age due to the depletion of cell-mediated immunity to Varicella-Zoster Virus (VZV). Complications are associated with excess of morbidity, but also are thought to be associated with an increase of the costs for the health care system. 
An effective and safe, live attenuated varicella-zoster virus vaccine has proved to reduce the burden of illness due to herpes zoster among people 60 years of age or older, as well as the morbidity from post-herpetic neuralgia among older adults [7]. A thorough epidemiological surveillance and a good understanding of the burden of diseases associated to VZV are crucial to asses any potential impact of a prevention strategy.

Hospital discharge databases provide a complete record of all hospitalizations and are not subject to under-diagnosis and deficiencies in reporting that usually limit surveillance systems of outpatient diseases. Additionally, hospitalization databases measure the most severe part of the disease spectrum, herpes zoster in this case [8].

The aim of this study was to estimate the burden of hospital admissions for herpes zoster in persons $\geq 30$ years of age, in Spain during a 7-years period (1998-2004).

\section{Methods}

A retrospective study was conducted by using discharge information obtained from the national surveillance system for hospital data maintained by the Ministry of Health, Conjunto Mínimo Básico de Datos (CMBD). This database records all hospital admissions, with an estimated coverage of $97.7 \%$ in public hospitals and $25 \%$ in private clinics $[9,10]$. However, private hospitals represent a small proportion of all hospital admissions, as public healthcare insurance is covering almost $100 \%$ of the Spanish population [11]. Diagnosis is codified according the Spanish version of the International Classification of Diseases, $9^{\text {th }}$ Revision, Clinical Modification (ICD-9-CM) [12]. Hospital discharge data have been previously shown to be an important source of information for assessing the burden of diseases such as varicella, rotavirus or pneumonia and different types of cancer [13-17]

All hospital discharges with a primary or secondary diagnosis of herpes zoster (ICD-9-MC codes 053.0-053.9) during a 7-year period (1998-2004), were obtained. For each case data were gathered on age, Region of hospitalization, first and secondary diagnosis, type of discharge (death, recovery, other) and length of hospital stay. Costs related to hospitalization were estimated by using the Diagnosis Related Groups (DRG) system, which classifies hospitalizations into groups that are expected to generate similar use of hospital resources. Classification is based on diagnoses, procedures, age, presence of complications and co-morbidities [18]. Each group has similar weight in hospital costs and can be apply to each related patient. GRDs calculations are made by $3 \mathrm{M}$ with Core Grouping System Software [19]

\section{Statistical methods}

The unit of analysis was the hospital admission. The average annual number of hospitalizations for herpes zoster (ICD-9-CM codes 053, 053.0-053.9) in patients $\geq 30$ years of age, annual hospitalization rate (annual number of hospital admissions per 100,000 population), average length of hospital stay (ALOS), mortality rate (annual number of deaths at hospital per 100,000 population) and case-fatality rate (annual number of deaths at hospital/annual number of hospital admissions; \%) were calculated. The Spanish population obtained from the 19982004 census projection and adjusted to the $97.7 \%$ of the population covered by hospitals included in the CMBD was used as denominator. It was assumed that the distribution by age of the population covered by public hospitals was equal to the distribution of the general population. The age-standardized hospitalization rates were calculated for the different Autonomous Regions by direct standardization. The standard reference population of the EU was used for this calculation. The frequency of co-morbidities and complications related to herpes zoster was assessed by studying the distribution of the co-existent and subsequent codes to $\mathrm{HZ}$, respectively. The cost of these hospitalizations for the health care system was calculated by considering the diagnosis-related groups (DRGs), the total cost and the number of discharges. ANOVA was used for multiple comparisons. The post hoc Bonferroni correction was used to adjust statistical significance for multiple comparisons. The individual cost of a hospitalization was calculated by dividing the total annual cost (all DRG costs per year) by the total number of admissions per year.

Cases of herpes zoster were stratified by age group: 30-49 years; 50-59 years; 60-69 years; $70-79$ years; $\geq 80$ years. Data were processed and analyzed using SPSS software for personal computers (version 14.0; Chicago, Ill, USA). The study was approved by the Research Ethics Committee of the Hospital 12 de Octubre (Madrid).

\section{Results}

A total of 23,584 hospital discharges with a primary or secondary diagnosis of herpes zoster were identified during the 7 -years study period (an annual average number of 3,369 admissions). The mean age (SD) of these patients was 68.3 (15.5) years of age, respectively. Fifty-two percent of the patients were men and more than $85 \%$ of these hospitalizations were in population older than 50 years of age (Table 1). The annual hospitalization rate for herpes zoster was of 13.4 hospital admissions per 100,000 population $\geq 30$ years of age. This rate increases with age reaching a maximum in population $\geq 80$ years of age (54.3 admissions per 100,000 population) (Table 1). 
Table I: Hospitalizations for herpes zoster per group of age

\begin{tabular}{cccccc}
\hline $\begin{array}{c}\text { Age } \\
\text { (years) }\end{array}$ & Cases & $\begin{array}{c}\text { Hospitalization rates } \\
\text { (cases per 1 00,000 (IC95\%)) }\end{array}$ & $\begin{array}{c}\text { Average length } \\
\text { of stay (days)(SD) }\end{array}$ & $\begin{array}{c}\text { Average } \\
\text { costs }\end{array}$ & $\begin{array}{c}\text { Total annual } \\
\text { costs (1999-2004) }\end{array}$ \\
\hline $\mathbf{3 0 - 4 9}$ & 3449 & $4.13(3.76-4.49)$ & $12.45(16.38)$ & $3,983.84 €$ & $1,967,352 €$ \\
$\mathbf{5 0 - 5 9}$ & 2348 & $7.44(7.14-7.75)$ & $13.00(16.41)$ & $4,078.98 €$ & $1,384,135 €$ \\
$\mathbf{6 0 - 6 9}$ & 4468 & $16.56(16.07-17.04)$ & $13.49(16.52)$ & $3,796.48 €$ & $2,451,261 €$ \\
$\mathbf{7 0 - 7 9}$ & 7362 & $32.87(32.12-33.62)$ & $12.90(13.57)$ & $3,616.04 €$ & $3,869,164 €$ \\
$>\mathbf{8 0}$ & 5957 & $54.33(52.95-55.70)$ & $12.59(12.36)$ & $3,500.53 €$ & $3,060,044 €$ \\
\hline Total & 23584 & $13.44(13.27-13.61)$ & $12.88(14.62)$ & $3,719.53 €$ & $12,731,955 €$ \\
\hline
\end{tabular}

A total of 1,092 deaths occurred among patients hospitalized for herpes zoster during the study period (an average of 156 deaths per year). The case-fatality rate was $4.6 \%$ during the study period, being of $7.2 \%$ among patients $\geq$ 80 years old (Figure 1 ). The mortality rate was 0.6 per 100,000 population, being of 3.9 per 100,000 population among patients $\geq 80$ years old (Figure 1 ). The average length of stay in hospital was 12.9 days (SD 14.6) (Table $1)$.

Figure 2 shows the average annual hospitalization rate for herpes zoster in the seventeen Autonomous Regions of Spain. Navarra has the highest hospitalization rate (20.1 per 100,000 population) and Canary Islands the lowest (6.1 per 100,000 population). The average length of hospital stay ranged from 10 days in Murcia to 20 days in Canary Islands.

Herpes zoster code was the first listed diagnosis in $27 \%$ of the discharges. In the other $73 \%$, the primary cause of hospitalization (first listed diagnosis) was mainly respiratory diseases (24\%) and cardiovascular diseases (19\%). When analysing first position diagnosis code, a 3.62 hospitalization rate (per 100,000 population) was found,

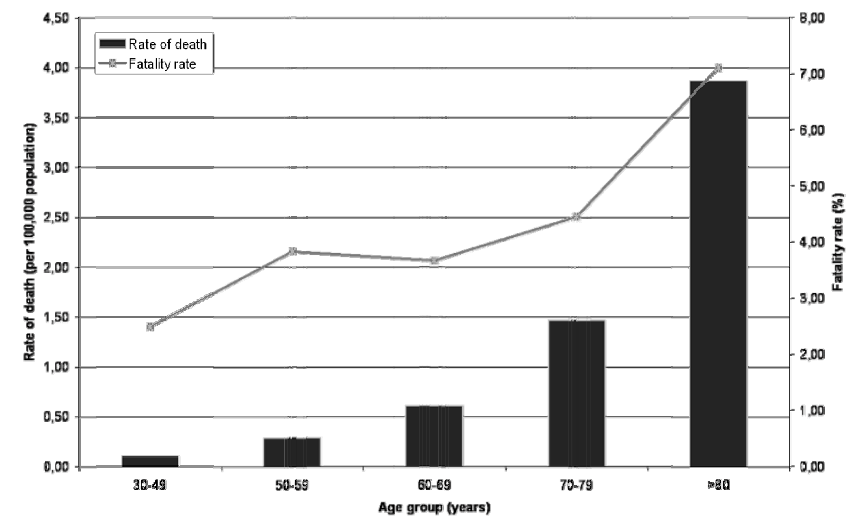

Figure I

Rate of death and fatality rate in patients hospitalized with herpes zoster by group of age in Spain (1998-2004). with a mean age of 68 years old and a mortality rate of 0.06 deaths per 100,000 population. The case-fatality rate was $1.68 \%$ and the hospitalization length of stay was 9.23 (SD 9.26).

Twenty-five percent of patients showed to have one or more diagnosis of co-morbid illnesses: leukaemia, other malignancies and HIV were the most frequent (9.6\%, $8.4 \%$ and $6.5 \%$, respectively), with HIV being the most frequent comorbidity $(40 \%)$ in the $30-49$ year-old patients.

Complications related with herpes zoster were present in $45 \%$ of admissions and neurological complications (28.6\%) were the most frequently documented conditions in all age groups.

The mean cost of a herpes zoster related hospitalization was $€ 3,720$. This figure was relatively stable among groups of age (Table 1). Therefore, hospitalizations for herpes zoster generate an annual expenditure in Spain of $€ 12,731,954$. When studying separately primary diagnose code, the mean cost per HZ episode was $€$ 3,200.

\section{Discussion}

Analysis of population-based hospital discharge data is a feasible, simple and sensitive way to monitor the occurrence of some diseases and their epidemiology. However, hospital discharge data have some limitations, including some potential biases associated to coding or the fact that a hospital discharge record represents a single hospital admission, and so a single patient admitted more than once will have multiple records [20]. In addition, it was not possible to determine whether herpes zoster was the main cause of the hospitalization. Other limitations are the lack of data on disease severity, medication or use of procedures, such as mechanical respiration, or intensive care stay, all of which are important determinant of hospitalizations usage and costs. [21] However, an outpatient study of herpes zoster in which case finding was based on diagnostic codes, including ICD-9 codes, found an $89 \%-$ $96 \%$ positive predictive value of a diagnostic code of herpes zoster. [22] 


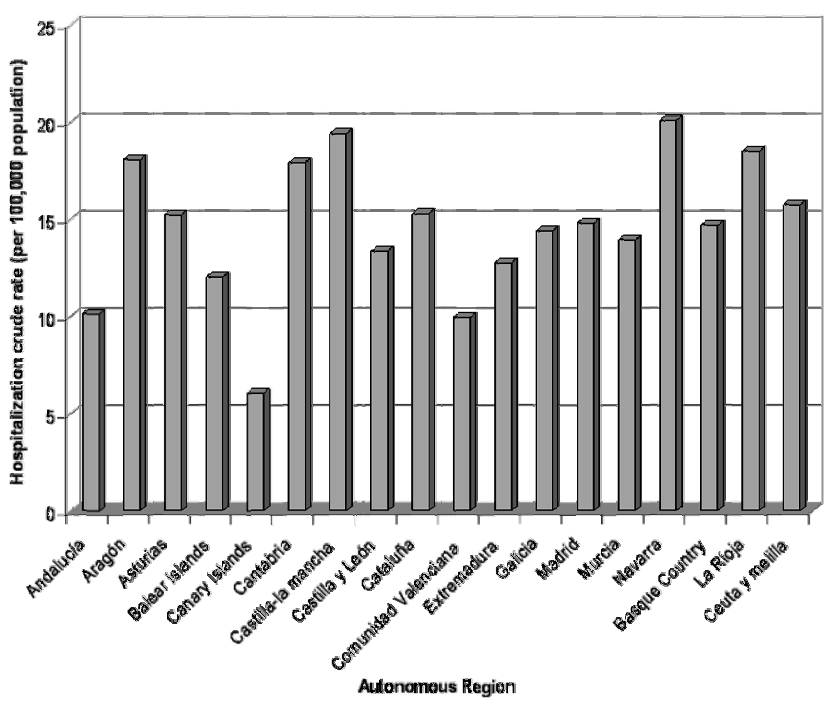

Figure 2

Hospitalization crude rate due to herpes zoster in Spain (1998-2004).

More than 23,584 hospitalizations for herpes zoster occurred during the 1998-2004 period, which means an annual hospitalization rate of 13.4 per 100,000 population $\geq 30$ years of age for herpes zoster. Our figures are consistent with those found in other studies in USA and Europe using population-based data including general practitioner sentinel surveillance, hospitalisation data, and death certificates. The existing data on the incidence of hospitalization for herpes zoster in Spain is 8.4 per 100,000 population [13]. Studies in the United States and England and Wales show an incidence of herpes zosterrelated hospitalizations of 16.1 and 4.4 per 100,000 population, respectively.[8,23] Mainly due to differences in the Health National Systems and criteria for hospitalization of adult patients.

Age-specific rate of hospitalizations increased sharply with age, especially after the age of 50 years, reaching 54.3 hospitalizations per 100,000 persons at $\geq 80$ years of age. This finding matches with the pattern of incidence of herpes zoster described in developed countries, where most of the burden of severe zoster occurs in adults $\geq 50$ years of age $[24,25]$.

There were some differences among regions in relation to the rate of hospitalizations. These differences may be attributed to variability in the reporting system and coding, and also to factors related to the patient condition (mainly age and comorbidity) and the health system (availability of hospital beds per 100,000 population, clinical procedures). The lower hospitalization rate in the Canary Islands could be explained by its special geo- graphic characteristics, as they are in a tropical area, where the VZV seroprevalence is possibly lower than in temperate areas.

Neurological conditions were the most frequent complication in patients hospitalized for herpes zoster. This has been previously shown in a study carried out in Finland [26]. Persons with underlying comorbidity, such as leukaemia or HIV have an increased risk of presenting zosterrelated complications. Anyway, immunocompromised patients will not be prevented by vaccination with the live attenuated varicella-zoster virus vaccine, such admissions might be minimally or non modified by a vaccine-based prevention strategy.

Hospitalization rate, mortality rate and case-fatality rate found for any diagnose position were four, ten and threefold those for $\mathrm{HZ}$ as first diagnosis position, respectively. The hospitalization length of stay was 4 days shorter. This indicates the importance of underlying co-morbidities, that can increase the severity of a herpes zoster episode. The cost for a primary diagnose of $\mathrm{HZ}$ was $€ 520$ cheaper.

The estimated annual cost of hospitalizations for herpes zoster in adults in Spain will be of 12.7 million $€$. This figure will be higher when indirect costs are also considered.

\section{Conclusion}

Herpes zoster is a costly disease that disproportionately affects the elderly. It imposes an important burden of hospitalizations and result in large cost expenses to the Spanish National Health System, especially in population older than 50 years of age

\section{Competing interests}

MSM and AG are employees of Sanofi Pasteur MSD, Madrid, Spain.

\section{Authors' contributions}

AG: study design and its coordination, RG draft the manuscript and review of statistics, AA: statistical analysis, MSM study design, draft the manuscript and study coordination, AG: study design, all the authors have reviewed and approved the final manuscript.

\section{Acknowledgements}

To the Subdirección General del Instituto de Información Sanitaria for providing with the information in which this study is based.

Founding sources: This study was supported by a research grant of Sanofi Pasteur MSD

\section{References}

I. Vázquez M, Shapiro ED: Varicella vaccine and infection with varicella-zoster virus. N Engl J Med 2005, 352(5):439-40.

2. Galil K, Choo PW, Donahue JG, Platt R: The sequelae of herpes zoster. Arch Intern Med 1997, I 57( I I): 1209-13. 
3. Hope-Simpson RE: Postherpetic neuralgia. JR Coll Gen Pract 1975, 25(I57):57I-5.

4. Edmunds WJ, Brisson M, Rose JD: The epidemiology of herpes zoster and potential cost-effectiveness of vaccination in England and Wales. Vaccine 200I, 19(23-24):3076-90.

5. Helgason S, Petursson G, Gudmundsson S, Sigurdsson JA: Prevalence of postherpetic neuralgia after a first episode of herpes zoster: prospective study with long term follow up. BMJ 2000, 32I(7264):794-6.

6. De Moragas JM, Kierland RR: The outcome of patients with herpes zoster. AMA Arch Derm 1957, 75(2): 193-6.

7. Oxman MN, Levin MJ, Johnson GR, Schmader KE, Straus SE, Gelb LD, Shingles Prevention Study Group, et al: A vaccine to prevent herpes zoster and postherpetic neuralgia in older adults. $N \mathrm{Engl}$ J Med 2005, 352(22):227।-84.

8. Lin F, Hadler JL: Epidemiology of primary varicella and herpes zoster hospitalisations: the pre-vaccination era. J Infect Dis 2000, I8I: : 897-905.

9. Subdirección General de Desarrollo: Instituto Nacional de Salud. Ministerio de Sanidad y Consumo. Conjunto Mínimo Básico de Datos. Hospitales de Insalud 200I [http://www.ingesa.msc.es/estadEstu dios/documPublica/pdf/grds-200I.pdf]. (Accessed April 2009).

10. Rivero Cuadrado A: El conjunto mínimo básico de datos en el SNS: inicios y desarrollo actual. Rev Fuentes Estadísticas 2000, 49: 18-19 [http://www.ingesa.msc.es/estadEstudios/documPublica/pdf/ CMBD-200I.pdf]. (Accessed April 2009).

II. Sevilla F: La universalización de la atención sanitaria. Sistema Nacional de Salud y Seguridad Social. Fundación Alternativas. Documento de trabajo 86/2006 [http://www.seg-social.es/ stpri00/groups/public/documents/binario/51587.pdf]. (Accessed April 2009).

12. Ministerio de Sanidad y Consumo: Clasificación Internacional de Enfermedades 9 a revisión, modificación clínica. [http:// www.msc.es/estadEstudios/estadisticas/normalizacion/clasifEnferm/ home.htm]. (Accessed December 2007).

13. Gil A, San-Martín M, Carrasco P, González A: Epidemiology of severe varicella-zoster virus infection in Spain. Vaccine 2004, 22:3947-5I

14. Gil A, Carrasco P, Jiménez R, San-Martín M, Oyagüez I, González A: Burden of hospitalizations attributable to rotavirus infection in children in Spain, period 1999-2000. Vaccine 2004, 22:2221-2225.

15. Gil A, San-Martín M, Carrasco P, González A: Epidemiology of pneumonia hospitalizations in Spain, 1995-1998. Journal of infection 2002, 44:84-87.

16. Penberthy L, McClish D, Pugh A, Smith W, Manning C, Retchin S: Using hospital discharge files to enhance cancer surveillance. Am J Epidemiol 2003, 158:27-34.

17. Middleton RJ, Gavin AT, Reid JS, O'Reilly D: Accuracy of hospital discharge data for cancer registration and epidemiologica research in Northern Ireland. Cancer Causes Control 2000 I I:899-905.

18. Ministerio de Sanidad y Consumo: Análisis y desarrollo de los GDR en el Sistema Nacional de Salud. [http://www.msc.eestadEstudios/estadisticas/inforRecopilaciones/anaDesarrol loGDR.htm]. (Accesed December 2007)

19. Schreyögg J, Stargardt T, Tiemann O, Busse R: Methods to determine reimbursement rates for diagnosis related groups (DRG): a comparison of nine European countries. Health Care Manag Sci 2006, 3:215-23.

20. Huff L, Bogdan G, Burke K, Hayes E, Perry W, Graham L, Lentzner H: Using hospital discharge data for disease surveillance. Public Health Rep 1996, I I 1:78-8I.

21. Galil K, Brown C, Lin F, Seward J: Hospitalizations for varicella in the United States, 1988 to 1999. Pediatr Infect Dis J 2002, $21(10): 93 I-5$.

22. Miller E, Marshall R, Verdien J: Epidemiology, outcome and control of varicella-zoster infection. Rev Med Microbiol 1993, 4:222-30.

23. Brisson M, Edmunds W]: Epidemiology of Varicella-Zoster Virus in England and Wales. J Med Virol 2003, 70(Suppl I):S9-14

24. LaRussa P: The success of varicella vaccine. Pediatr Ann 2002, 3 I(II):7I0-5.

25. Bramley JC, Jones IG: Epidemiology of chickenpox in Scotland: I98I to 1998. Commun Dis Public Health 2000, 3(4):282-7.
26. Koskiniemi M, Piiparinen H, Rantalaiho T, Eranko P, Farkkila M, Raiha $K$, Salonen EM, Ukkonen P, Vaheri A: Acute central nervous system complications in varicella zoster virus infections. J Clin Virol 2002, 25(3):293-30I.

\section{Pre-publication history}

The pre-publication history for this paper can be accessed here:

http://www.biomedcentral.com/1471-2334/9/55/prepub
Publish with Biomed Central and every scientist can read your work free of charge

"BioMed Central will be the most significant development for disseminating the results of biomedical research in our lifetime. "

Sir Paul Nurse, Cancer Research UK

Your research papers will be:

- available free of charge to the entire biomedical community

- peer reviewed and published immediately upon acceptance

- cited in PubMed and archived on PubMed Central

- yours - you keep the copyright
BioMedcentral 